Trivent Publishing

(C) The Authors, 2015

Available online at http://trivent-publishing.eu/

Philosophy, Communication, Media sciences Series

Volume Saint Gerard of Cenad: Tradition and Innovation

\title{
The Bollandists' Life of Saint Gerard
}

\author{
Boris Stojkovski \\ University of Novi Sad, Faculty of Philosophy, Department of History \\ Novi Sad, Serbia, stbs@ptt.rs
}

\begin{abstract}
In this paper I will provide some commentaries on the structure of the Bollandists' "Life of Saint Gerard," which can be found in the sixth volume of the Acta Sanctorum Septembris. The Life itself consists of four parts: a sort of preface, i.e. a historical commentary, a chronology of the most important events in the life of Saint Gerard and Vita, which is, in fact, a version of the well-known Legenda minor, and some appendices. The foreword is of the most scholarly value because it lists many interesting older works used by the Bollandist writer.
\end{abstract}

\section{Keywords}

Saint Gerard of Cenad; Acta Sanctorum; Bollandists; Legenda minor; hagiography

This paper presents parts of the findings from research for the project Vojvodina In The Context Of European HistoryВојвођански простор у контексту европске историје (no. 177002), financed by the Ministry of Education and Science of the Republic of Serbia.

This is an Open Access article distributed in accordance with the Creative Commons Attribution Non Commercial (CC-BYNC-ND 4.0) license, which permits others to copy or share the article, provided original work is properly cited and that this is not done for commercial purposes. Users may not remix, transform, or build upon the material and may not distribute the modified material (http://creativecommons.org/licenses/by-nc/4.0/)

DOI: $10.22618 /$ TP.PCMS.20151.176008 


\section{Introduction}

The Roman Catholic Church has venerated Saint Gerard of Cenad for more than nine centuries. His life and martyrdom can be found in almost every collection of the Lives of the Saints of the Roman Catholic Church. Therefore, it is logical and expected that this saint is also mentioned and described in the Acta Sanctorum. This paper focuses on the section in the Acta Sanctorum referring to the Life of Saint Gerard of Cenad. The Bollandists' Life of Saint Gerard has been widely used in historical studies, but mostly only the brief Vita that is incorporated into a much larger and more extensive hagiographical unit in the Acta Sanctorum Septembris. Hence, the aim of this paper is to give an overview of the entire Life of Saint Gerard of Cenad contained in the Acta Sanctorum. It will provide an explanation of the contents of the Life of Saint Gerard and to more profoundly study the sources that were used. It should first be pointed out that the largest value of this hagiographic piece is the use of some older works, particularly from the late medieval and early modern periods, and some rarely used sources.

This paper will present this Bollandist hagiographic work, its contents, value and the sources used for this peculiar and very interesting account of Saint Gerard of Cenad. The sources, i.e. works by earlier authors, that the Bollandist hagiographer consulted and cited in this edition of the Life of Saint Gerard of Cenad are not always the most reliable. Therefore, this paper will try to provide a critical overview of these sources or works by other medieval and early modern authors and to attempt to make additional attempts to understand these sources and their background. The Bollandist author used a vast number of different bibliographical units. The criticism provided by this author is quite good, considering the fact that in the $18^{\text {th }}$ century critical hagiography and historical science were not fully developed. Nevertheless, there were many omissions and errors which emanated from the use of unreliable sources. However, all this is a consequence of the period in which the Acta Sanctorum was written, as well as certain mistakes and oversights by the author himself. It is also important to note that the author of the Life of Saint Gerard used the works that were accessible to him, although some of them were not representative works.

\section{Authorship, structure and manuscripts}

Without a doubt, the Acta Sanctorum is one of the key sources for hagiographical research of almost any kind. This is particularly important for those researching the saints of the ancient and early medieval Christian church, as well as Roman Catholic saints of the medieval and early modern periods. One of the medieval Roman Catholic saints who found his place in this extensive publication is Saint Gerard of Cenad. The Life of Saint Gerard, or as it was originally entitled in the Acta Sanctorum: De Sancto Gerardo episcopo martyre prope Danubium in Hungaria, is of particular interest. This Life of Saint Gerard of Cenad was published in the sixth volume of the Acta Sanctorum Septembris, which was printed in 1757 in Anvers/Antwerp. The author of this Vita was the Jesuit Johannes Stilting (1703-1762), also known among researchers of hagiography (an in particular, those interested in medieval Hungary) for his Vita Sancti Stephani regis Hungariae. He was one of the key scholars who continued the work of Jean Bolland himself, even though they never actually met due to Bolland's much earlier death. Stilting was the author of almost 250 hagiographic works in the Acta Sanctorum. His first bibliographical units and lives of the saints were written in the first volume for the month of August which covered the saints celebrated on the fifth of the month, and finished with the saints whose lives were described in the first volume and on the first day of the month of October. It is noteworthy that Johannes Stilting worked in the Hungarian libraries for some time alongside Constantine Suyskens (1714-1774), another prominent Bollandist who wrote around 130 articles in the 
Acta Sanctorum. They worked together in Germany, France and the Habsburg Empire (Hungary) from 1752-1753; they had even an audience at the court of the Austrian Empress Maria Theresa. Besides Vita Sancti Stephani regis Hungariae the most prominent works of Joannes Stilting are the Acta Sancti Aurelii Augustini, Acta sanctae Rosaliae (perhaps his most famous work), in addition to some other Vitae and Acta he also wrote Quaestio an verissimilie sit S. Paphnulium se in concilio Nicaeno opposuisse legi de continentia sacerdotum et diaconorum. ${ }^{1}$

The part in the Acta Sanctorum Septembris dedicated to Saint Gerard comprises almost 14 full pages (pp. 713-727). ${ }^{2}$ In the historiography and hagiography, the authors mostly relied only on the brief Vita, which will be addressed later. This is not of such great significance for either history or hagiography even though it is generally significant and interesting. However, the structure is slightly different. The Bollandist chapter dedicated to Saint Gerard can be divided into the five chapters or sections of this hagiographic work. The first and the largest section is De Sancto Gerardo episcopo martyre prope Danubium in Hungaria commentaries praevius, which is a kind of preface, but is more extensive than the Vita itself. ${ }^{3}$ The second part is a chronology of the life of Saint Gerard of Cenad, followed by an analysis of different sources, and is also longer than the actual Vita. ${ }^{4}$ The veneration and cult of Saint Gerard is the key topic of the third chapter of the De Sancto Gerardo episcopo martyre prope Danubium in Hungaria. ${ }^{5}$ Only the fourth part is the Vita, which is simply another version of well-known Legenda minor. ${ }^{6}$ At the end, there are two very valuable and remarkable appendices, which will be discussed in further detail. ${ }^{7}$

At the very beginning of the first chapter entitled De Sancto Gerardo episcopo martyre prope Danubium in Hungaria commentaries praevius, the author, Johannes Stilting, mentions the manuscript according to which he published the Vita of the Bishop of Cenad. It is a manuscript from the Augustinian (Canons Regular) priory of Corsendonck/Corsendonk in Brabant ${ }^{8}$ (now a famous Belgian brewery and a hotel complex). According to Stilting, the same manuscript was, re-published in Krakow in 1511. It is in fact an edition of the Life of Saint Stanislas, Bishop of Krakow by the wellknown Polish medieval historian, Jan Dlugosz. ${ }^{9}$

To date, scholars are aware of three manuscripts of the Saint Gerard's Legenda minor, which is the core of the Bollandists' Life of Saint Gerard of Cenad. The first one is the Codex Venetus, which is kept in the Biblioteca Nazionale di San Marco in Venice. This codex originates from the $13^{\text {th }}$ century. A younger manuscript is the Codex Parisiensis, which is in fact the previously mentioned manuscript from abbey of Corsendonk. This manuscript dates from the end of the $15^{\text {th }}$ century, and is now in the Bibliothèque Mazarin in Paris. The last one is from the Legende Sanctorum Hungariae, a compilation of the lives of different saints that did not enter into the Legenda aurea (Golden Legend). The first

${ }^{1}$ K. J. Derks, "Stilting (Joannes)." In P. C. Molyhusen en P. J. Blok (eds.), Nieuw Nederlandsch Biografisch Woordenboek, Tweede deel (Leiden: A. w. Sijthoffs Uitgevers-maatschappij, 1912), col. 1376-1377; idem, "Suyskens (Constantinus)." NNBW II, col. 1396-1397.

${ }^{2}$ Acta Sanctorum septembris, tomus sextus (Antverpiae: 1757), 713-727.

${ }^{3}$ AA SS septembris VI, 713-715.

${ }^{4}$ AA SS septembris VI, 715-719.

${ }^{5}$ AA SS septembris VI, 719-722.

${ }^{6}$ AA SS septembris VI, 722-724, with the annotata in pp. 724-725.

${ }^{7}$ AA SS septembris VI, 725-727. It also has annotata on p. 727.

${ }^{8}$ On the history of this abbey cf. Ch. Van Hulthem, dél., Bibliotheca Hulthemiana. Manuscrits (Gand, 1837), 147; Joseph Delmelle, Abbayes et béguinages de Belgique (Bruxelles: Rossel Édition, 1973), 41.

${ }^{9}$ Ian Dlugossus, Vita beatissimi Stanislai Cracoviensis Episcopi. Nec non Legendae Sanctorum Poloniae, Hungariae, Bohemiae, Moraviae, Prussiae et Slessiae patronorum, in Lombardica historia non contentae. (Cracoviae: 1511), 239-243. 
edition is from 486-489, which was printed in Strasbourg. One version of the Life of Saint Gerard (the Legenda minor) was reprinted and edited by Dlugosz in the work previously mentioned. ${ }^{10}$

\section{The Bollandists' Life of Saint Gerard: structural analysis}

In the opening of this chapter dedicated to Saint Gerard, Joannes Stilting first provides strong criticism of earlier authors who had either written the Life of Saint Gerard or about it. His critique is first directed towards the work of Laurentius Surius, a German Carthusian hagiologist and church historian. Surius wrote and compiled De probatis Sanctorum historiis, a well-known work often cited in the early modern period, that was first published in $1575 .{ }^{11}$ Stilting then mentions a Benedictine monk named Arnold Wion (1554-1610) as being the least knowledgeable source and who had made numerous mistakes in his version of the Life of Saint Gerard. Wion wrote a work printed in 1597 in Venice under the title Vita S. Gerardi, e Veneta familia de Sagredo, martyris et Hungarorum apostoli, notationibus illustrata. Like all of Wion's other works (the most well-known being a history of the Benedictine order known as the Lignum Vitce) the Life of Saint Gerard is full of mistakes and has been widely criticized by many for its lack of seriousness. Nevertheless, it was widely used and quoted. One of the authors who made extensive use of the works of Wion was Jean Mabillon, another Benedictine monk from France, known as the father and the founder of paleography and diplomacy. Mabillon also wrote the Acta Ordinis S. Benedicti where he discusses Gerard and quotes Wion. This is firmly opposed by Stilting. ${ }^{12}$

In the Commenatarius praevius Stilting pointed out some of the most, in his words, "patently ridiculous" mistakes by earlier authors, especially Arnold Wion. For instance, there is a well-known part in the Vita of Saint Gerard (in both the Legenda maior and Legenda minor) where it is written that Gerard was preparing to go on a pilgrimage to the Holy Land, but his ship was stopped on the Dalmatian coast. Gerard never went on to fulfill his wish to complete the pilgrimage, and instead left for Hungary. Stilting disagrees with Wion, stating that Wion had written in his Life of Saint Gerard that Saint Gerard had in fact preached at the monastery of Saint Jerome in Bethlehem, in the Holy Land. This certainly false information most probably was derived from a part in Legenda Maior where it is stated that Gerard wished to visit this monastery in the event of being able to visit the Holy Land.

\footnotetext{
${ }^{10}$ For manuscripts and edition see Szovák Kornel-Veszprémy László, "Krónikák, legendák, intelmek-utószava" In: Scriptores rerum Hungaricarum II, ed. Emericus Szentpétery, Budapestini, 1999, 781; [Szovák KornelVeszprémy László, "Chronicles, legends, institutions-epilogue"] On the Legendae sanctorum and Legenda aurea cf. Tóth Péter, "Szent Demeter magyarországi legendája” In: Tóth Péter (ed.), Szent Demeter. Magyaroország elfeledett védöszentje (Budapest: Balassi, 2007), 44-47 [Tóth Péter, "The Hungarian legend of Saint Demetrius" In: Tóth Péter (ed.), Saint Demetrius. The Forgotten protector saint of Hungary]; Legendae sanctorum regni Hungariae is digitalized and accessible at (links here are for the Life of Saint Gerard) http://oszkdk.oszk.hu/storage/00/00/41/72/dd/1/Inc 463 0025.html http://oszkdk.oszk.hu/storage/00/00/41/72/dd/1/Inc_463_0026.html http://oszkdk.oszk.hu/storage/00/00/41/72/dd/1/Inc 463 0027.html all accessed on January 11, 2015

${ }^{11}$ According to Stilting, the work of Surius on Saint Gerard was mutato stylo, AA SS septembris VI, 713. On Surius see Hildegard Hebenstreit-Wilfert, Wunder und Legenden. Studien zu Leben und Werk von Laurentius Surius (1522-1578) (Universität Tübingen 1975).

${ }^{12}$ AA SS septembris VI, 713-714. Stilting also criticizes Wion for using only two out of five editions of Gerard's Vita in his own edition of the Life of Saint Gerard. Stilting further argues how and why Wion did not use earlier editions. About Wion and his work cf. Réginald Grégoire OSB, "Wion, Arnold, bénédictin († 1613, ou 1610)", Dictionnaire de spiritualité, t. 16: U-Z, Ubald d'Alençon-Zypaeus, (Paris: Beauchasne, 2004) col. 14791482.
} 
There are also further examples which will not be dealt with here. However, it should be noted that Stilting provides additional criticism of earlier compilers of the life of this Hungarian protomartyr. ${ }^{13}$

The next chapter is entitled Chronotaxis Vitae supplementum ex aliis scriptoribus et asserta variorum exainata. As the title itself suggests, here Stilting provides a chronology of Gerard's life drawn from different sources, then combining them and challenging those not consistent with each other. Here he also challenges information given by Wion including disputing the year of Gerard's birth. In this chapter, Johannes Stilting studies different aspects of Saint Gerard's life, for example his origin or his arrival in Hungary and the foundation of the Church of Cenad. He discusses the year of Gerard's arrival to Hungary, stating that he thinks that Gerard arrived in Hungary around 1030, while he places the foundation of Bishopric of Cenad around 1037. Stilting very strongly argues the chronology of the foundation of the Bishopric of Cenad, and provides an extensive chronology of the rule of Saint Stephen and the most important events from 1000 until his death. The purpose of this was to provide, as accurately as possible, the date the new bishopric was founded. ${ }^{14}$ In addition, Stilting argues with some earlier authors that Gerard also founded the Servite monastic order or the order of the Carmelites. ${ }^{15}$

In the following paragraphs Stilting then mentions parts from the Legenda maior of Saint Gerard and discusses events from the life of Saint Gerard and some details about the Cenad bishopric, but with some omissions and errors. It is pointing out that Stilting did not have critical editions of almost any source, nor was he familiar with Hungarian medieval history in depth. Concerning the Cenad bishopric, in the Acta Sanctorum Saint Gerard is described as episcopus Morisanae who built a monastery in Bel, and it is argued that in he lived in this monastery alongside a monk named Mauricius. There is no historical evidence for this, since this passage in the Legenda maior follows the hagiographic topos from the life of Saint Benedict in the Legenda aurea. ${ }^{16}$ Although on the other hand, Mauricius was the Bishop of Pécs who, according to the Legend Maior, invited Gerard and brought him to Hungary. Another important point to note is that the monastery in Bakonybél is dedicated to Saint Mauricius. Therefore, there a mistake must have been made by combining these

${ }^{13}$ AA SS septembris VI, 714-715. Cf. SRH II, 481.

${ }^{14}$ The date of the founding of the Bishopric of Cenad could be mostly accepted as quite precise and correct, since in the historiography an opinion is adopted according to which the Bishopric of Cenad was founded after 1030, cf. Juhász Kálmán, A csanádi püspökség története. Alapitásától a tatárjárásig, (Makó: Csanád vármegye közönsége 1930), 37-46 [Juhász Kálmán, The history of the bishopric of Cenad. From founding to the Tartar invasion]; Györffy György, István király és müve (Budapest: Gondolat, 1983), 296, 326, 366-367 [Györffy György, Saint Stephen and his work]; Vincent Múcska, 'Az első magyarországi püspökségekröl' Fons XII (2005): 23, 27. [Vincent Múcska, "On the first Hungarian bishoprics"]; Zsoldos Attila, Magyarországi világi archontológiája 1000-1301, (Budapest: MTA TTI, 2011), 86 [Zsoldos Attila, The laic arhcontology of Hungary 1000-1301].

15 AA SS septembris VI, 716-717. For example, Filippo Ferrari (1551-1626) was a Servite monk, geographer and hagiographer who composed one work entitled Catalogus sanctorum Italiae in Menses duodecim distributus. This book was published in 1613, and there Ferrari writes that Gerard was the founder of the Servite order. Philippus Ferrarius Alexandrinus, Catalogus sanctorum Italiae in Menses duodecim distributus, (Mediolani: Bordonius, 1613), 115-116. Stilting criticizes this opinion, stating that the Servite order was founded almost two centuries after the death of Saint Gerard. The same criticism was directed towards the work of Juan Baptista Lezano, a Spanish Carmelite theologian and writer, best known for the Annales sacri, Profetici et Eliani Ordinis Beatissimce Virginis Maria de Monte Carmelo published in Rome in 1656. He was an authority on canon law and theology, but as a historian, he was quite poor. Johannes Stilting cites Mabillon who already corrected some of Arnoldus Wion's the mistakes concerning Gerard as the founder of the Carmelite order. Mabillon also, according to Stilting, corrected Johannes Trithemius, author of the Annales Hirsaugienses. This German monk and occultist wrote that Saint Gerard founded monastery of Saint Gregory in Rome, which is false. cf. AA SS septembris VI, 716.

${ }^{16}$ Előd Nemerkényi, Latin Classics in Medieval Hungary. CEU Medievalia VI (Debrecen-Budapest: University of Debrecen-Central European University, 2004), 75. 
events. As far as monastery in Bakonybél is concerned, Stilting is a bit confusing here. He came to a very interesting conclusion, which was that Gerard did not live in the monastery, but in a place called Bél in the woods of Bocon where he had made some kind of monastic cell for himself. Even though the Legenda maior mentions that he built himself some kind of a small room or cell where he had lived as a hermit and where he had fasted, prayed and wrote his numerous works, uncertainties still remain about this part of the Gerardüs legends. King Stephen I, on the recommendation and advice of Saint Gunther, cousin of Queen Gizella, most probably founded the actual monastery. It is even argued in the Acta Sanctorum whether Gerard was an abbot of the monastery or a monk at the church in Cenad. ${ }^{17}$

Stilting also discusses the last years of Saint Gerard's ministry, and he mentions a work called Ovo Rex, which is most probably the name of the Hungarian king Aba Samuel. It is worth noting once more that he often relied on some non-critical editions of the sources, and not only in connection to this part. He also made extensive use of a work by János Thuróczy, who is not a contemporary source or particularly reliable in terms of early medieval Hungarian history. This is also true for Antonio Bonfini, whom Stilting also makes use of. For instance, Stilting had doubts as to whether the Bishopric of Cenad was founded after death of King Stephen I in 1038, since it had been mentioned by Bonfini. The last paragraphs of this chapter are dedicated to Gerard's final years and to his martyrdom. This is the least useful part for historians from the entire Bollandist Life of Saint Gerard of Cenad. It contains a dispute concerning the chronotaxis of the last years of the first Bishop of Cenad. Stilting mostly discusses the rule of Aba Samuel, Peter Orseolo, and the date of Saint Gerard's martyrdom. The Bollandist writer again mostly relies on Thuróczy and his Chronica Hungarorum which, as already mentioned, is not that trustworthy a source for the early medieval period of Hungarian history. ${ }^{18}$

The next part is dedicated to his relics, as well as his cult and devotion. In this chapter, entitled Posthuma sancti Gloria ex corporis translantionibus, canonizatione, cultu, miraculis, etc, the reader learns of Saint Gerard's canonization around 1083 during the time of Saint Ladislas. ${ }^{19}$ There is also a short paragraph on the veneration day of the saint, a story about the translation of his relics, and that some of his relics are allegedly in Prague. Stilting makes an omission here when he states that there is no information concerning Saint Gerard's funeral. When referring to saint's burial at the Church of the

${ }^{17}$ AA SS septembris VI, 717-718; SRH II, 481-490. On Gunther and the foundation of the monastery of Saint Mauricius Érszegi Géza, “Jegyzetek” in Érszegi Géza (ed.), Árpád-kori legendák és intelmek, ford. Csóka J. Gáspár et al., (Budapest: Szépirodalmi, 1987), 196 [Érszegi Géza, “"Notes” In: Érszegi Géza (ed.), The Legends and Institutions of the Age of Árpád]. See also Kühár Flóris, "Szent Gellért Bakonybélben” Pannonhalmi Szemle, II (1927): 304-319 [Kühár Flóris, "Saint Gerard in Bakonybél”].

${ }^{18}$ AA SS septembris VI, 718-719. The martyrdom of Saint Gerard is mostly described according to the Legenda maior, and Stilting quotes it, even though again his main source was also János Thuróczy. All chronological debates which Stilting writes about, are already well-known, and they consider the exact year of Aba Samuelüs coming to throne, come back toPeter Orseolo, and at the end, the precise date of his execution by the pagans. For establishing the exact date of Gerard's martyrdom, Stilting consulted Cesar Baronius, but also compared it with other authors like Mabillon or Samuel Pitiscus' Lexicon antiquitatum romanarum (printed in 1713). The (wrong) conclusion Stilting drew is that the Vata uprising occurred in 1047. To compare the text in Sacta Sanctorum and Legenda maior, see SRH II, 500-503. On the chronology of the events cf. Érszegi G, Jegyzetek, 198; Kristó Gyula, "Megjegyzések az ún. "pogánylázadások” kora történetéhez", Acta Universitatis Szegediensis de Attila József Nominatae. Acta Historica 18 (1965) 1-57 [Kristó Gyula, "The notes to the history of the so-called age of the pagan revolts']; idem, Szent István birodalma. A középkori Magyarország története (Budapest: HistóriaMTA TTI, 2001), 29-30 [idem, The Realm of Saint Stephen]; Font Márta (ed.), Dinasztia, hatalom, egyház. Régiók formálódása Európá közepén (900-1453) (Pécs, 2009), 290 [Font Márta (ed.), Dinasty, power, church. The formation of regions in the Central Europe (900-1453)].

${ }^{19}$ Cf. On that topic Klaniczay Gábor, “Az 1083. évi magyarországi szenttéavatások” in: Fügedi Erik (ed), Müvelödéstörténeti tanulmányok a magyar középkorról (Budapest: Gondolt, 1986), 15-33 [Klaniczay Gábor, "Hungrian canonizations in 1083" in: Fügedi Erik (ed.), Studies in medieval Hungarian cultural history]. 
Virgin Mary in Pest, Johannes Stilting quotes Arnold Wion and his edition of the Legenda maior. At that time it was the only edition of the Legenda maior Stilting could have used. Stilting almost consistently follows Legenda maior, but he also consults other Hungarian writers (sometimes referring to them as scriptores Hungarici without stating who they are). For instance, when he writes about a stone with the blood of Saint Gerard that could not be washed for seven years, he takes the story from the Legenda maior. Furhtermore, along with Bonfini and Thuróczy, Wion is also a main source, for the story about the translation of Saint Gerard's relics to Marosvár (Cenad), the seat of the bishopric he founded.

The following paragraphs of this chapter are dedicated to the days of veneration of Saint Gerard. Here, Stilting quotes and analyzes various martyrologues and gives his critical opinion. This was done in the manner of Jean Bolland himself (and later this methodology was further developed by Hippolyte Delehaye). According to them, martyrologues are one of the key sources, but they are not of equal value and one who studies them should approach them with caution. It is, though, very impressive that in the $18^{\text {th }}$ century Stilting managed to conduct a rather sophisticated critical evaluation of these peculiar sources. In this chapter, in particular, Stilting cites some of the martyrologues that places the celebration of Saint Gerard on February 23, which is the day of the translation of his relics to Murano. He corrects mistakes in different sources and explains omissions. In certain cases, when the dates had been mixed up, Stilting provided an explanation and corrigenda. Of course, as expected, the vast part of this chapter is about the adoration of Saint Gerard in Murano, where his relics had been translated. $\mathrm{He}$ is still very much respected there, and his relics are, even today, a place of pilgrimage for many believers from Hungary and other countries. At the end of this chapter, the Bollandist hagiographer writes about the relics (duo notabiliter magna ossa) of Saint Gerard allegedly located in Prague. In addition to Prague, Stilting mentions a part of the relics that were translated to Bologna, but has doubts about both of these possibilities. According to Stilting, no relics of Saint Gerard were donated anywhere prior to the transfer of his entire body to Murano. ${ }^{20}$

As was previously mentioned, Johannes Stilting mentions the miraculis, i.e. the miracles of Saint Gerard of Cenad. After the paragraph on the relics of Saint Gerard in Prague and Bologna, the chapter ends. The miracles are not mentioned anywhere in the Bollandist work on Saint Gerard, even though they are listed in the title of the chapter. It is widely known from the Legenda maior that many miracles were attributed to Saint Gerard of Cenad. For example, he cured a German girl of a cataract, many people recovered from swellings and sore eyes, and one of Saint George's canon priests recovered after three days from a massive stroke, all by the grace and miracles of Saint Gerard. Another priest named Peter recovered his eyesight while lying on a bier in Marosvár. Even the widow of comes Bech, who belonged to the circle close to the widow of Ajtony, was miraculously cured by

\footnotetext{
${ }^{20}$ AA SS septembris VI, 719-722; SRH II, 502-505. For his veneration in Venice cf. the newest study by Karen McCluskey, "Official Sanctity alla Veneziana: Gerardo, Pietro Orseolo and Giacomo Salomani", Conserverie mémorielles 14 (2013), http://cm.revues.org/1718 (accessed on January 10, 2015) as far as the possible transfer or donation of relics, the source he quotes concerning the Prague cathedral (Tomáš Jan Pešina z Čechorodu and his Phosphorus septicornis (Pragae: 1673). 518) does mention those relics. He also writes that those relics arrived there as a donation in 1304, which Stilting directly quotes. But, we find out from the later literature that there was no earlier mention in the inventories of Saint Vitus cathedral on the relics of Saint Gerard and some other saints mentioned by Pešina. The only relic that was brought to the cathedral from Hungary in 1304 was the blood of Saint Demetrius. Cf. Antonín Podlaha, Eduard Šittler, Chrámový poklad u sv. Víta v Praze : Jeho dějiny a popis. (Praha : Dědictví sv. Prokopa, 1903), 11, footnote 19 [The Church treasury of Saint Vitus in Prague. Its' history and description]. See also Ernő Marosi. "Saints at Home and Abroad. Some Observations on the Creation of Iconographic Types in Hungary in the Fourteenth and Fifteenth Centuries" in: Ottó Gecser et al. (eds.), Promoting the Saints. Cults and Their Contexts from Late Antiquity until the Early Modern Period. Essys in Honor of Gábor Klaniczy for his 60th Birthday, (Budapest-New York: CEU University Press, 2011), 188. As far as the Bologna problem is concerned, we find no evidence whatsoever.
} 
Saint Gerard when she visited his grave. These are just some of the miracles that have been attributed to Saint Gerard and were explained extensively in the Legenda maior. ${ }^{21}$ It is not clear why they were not incorporated into the Bollandist Life of Saint Gerard.

The most often cited part of this Life in the historiography and in critical hagiography is certainly the Vita itself, i.e. the hagiographic overview of the life of this saint, bishop, and martyr. This chapter is, in fact, another version and edition of the Legenda minor, or the Minor Legend of Saint Gerard. Even the question of which is older, the the Legenda maior or the Legenda minor, it is still a matter of debate among historians and other scholars, however, most researchers agree that this smaller, minor legend is actually a part of a liturgical scripture read during Church masses. The beginning of this legend (incorporated in the Acta Sanctorum by Stilting) clearly states that Gaudia, que Christi participibus dies hodierna contulit. The words dies hodierna could lead to the conclusion that this life of Saint Gerard was used in lectures on Church services.

If the currently most commonly used critical Latin editions of the text (from the second volume of the famous Scriptores rerum Hungricarum, in which a critical edition of Saint Gerard's legend is provided by Emericus Madzsar-Madzsar Imre), is compared with the Vita given in the Acta Sanctorum by the Stilting, it can be seen that the text is almost entirely the same. One of these differences is, for instance, the number of chapters. Madzsar has seven of in his edition in the Scriptores rerum Hungaricarum, while in the Bollandist Life of Saint Gerard of Cenad Joannes Stilting divided his edition of the Legenda minor into 13 chapters. It is not clear what the reasoning is behind the way Stilting decided to divide the chapters. Often there are no differences in the text or even in word order, but the structure of the chapters does not match. For instance, the end of the first and the beginning of the second chapter differ with this sentence: Igitur dum animi sinceritate sanctam vitam duceret, placuit ei Dominicum visitare sepulchrum, quatenus Christum, proper nos egenum factum, inops et pauper sequeretur. In the Bollandists' hagiographic work, the first chapter ends with this sentence, i.e. with the desire of Saint Gerard to visit the Holy Land and the Holy Sepulcher. However, in the edition of the Legenda minor by Madzsar this division of chapters (paragraphs) is more logical. In this edition, the future Bishop of Cenad's longing to make a pilgrimage is locatedat the beginning of the second chapter. The Vita then continues with the unsuccessful journey to the Holy Land, Gerard's arrival in Hungary, and so on. Since both texts are derived from almost the same manuscript, or better stated, manuscript and edition (with the already stated exclusion of the Codex Venetus), it is quite logical that the text itself would be very much alike. These imprecise divisions of chapters are not something that significantly changes the structure of the work, and neither do the more important language differences. Therefore, a closer inspection of the text of this Bollandist hagiographic work about this first Hungarian martyr and first Bishop of Cenad shows that the commenatrius previus and the addenda that come after the Vita itself would actually be more valuable and more interesting for study. A possible critical edition of this text would be very interesting, since it is a thought-provoking testament to early historical criticism in hagiography, as well as in connection with medieval Hungarian history. The Vita itself is yet another version of Legenda minor found in many editions, and of course, in the critical one that appears in the Scriptores rerum Hungaricarum. ${ }^{22}$

Next, two very important and interesting appendices can be found here. One of which is the Elogium provided in 1493 by Petrus Natalibus. It is a very brief life of this saint, and a valuable literary testament of the late medieval Renaissance. The historical value of his piece, the famous Catalogus sanctorum et gestorum eorum ex diversis voluminus collectus, editus a reverendissimo in Christo patre Domino Petro de Natalibus de Venetiis Dei gratia episcopo Equilino, has already been considered rather dubious by Daniel Paperbroch, another prominent Bollandist. The Elogium in the

\footnotetext{
${ }^{21}$ SRH II, 505-506.

${ }^{22}$ Cf. AA SS septembris VI, 722-725 and SRH II, 471-479.
} 
Bollandist Life of Saint Gerard of Cenad is from the 1493 edition published in Vicenza. It is very interesting that in this edition there is no mention of Gerard being from the noble Venetian Sagredo family. This only appears in the 1516 edition of Catalogus. In the 1543 edition, however, again, this supposed origin of Saint Gerard is omitted. ${ }^{23}$

The second appendix is another very interesting and outstanding document. These are lectures of the church in Murano, i.e. Lectiones officii antique ecclesiae Muranae. These six lectures were actually excerpted from the work of the $18^{\text {th }}$ century Italian writer and historian Flaminio Corner. ${ }^{24}$ There are some similarities in the lectures with the Legenda minor in the text as well as in the chronology of the life of Saint Gerard. In them can be found, for example, that Gerard was from the Sagredo family. The lectures also mention Pannonia a few more times than in the Legenda minor as the area where he preached and lived. Flaminio Corner persistently used Pannonia when referring to Hungary, naming even the country in which the king, and later saint, Stephen I lived and ruled as Christianissimus rex also as Pannonia. This is directly taken from Legenda minor, which is the key source for these lectures. If a comparison is made between these two texts, it can be seen that a vast majority of the scripture has been taken and copied directly from Legenda minor. Bigger differences can be found at the beginning, since in the Legenda minor there is no mention of Gerard's alleged origin from the Sagredo family from Venice, while in the first lecture this is the key message of the first sentence. ${ }^{25}$ Thus, the first lecture begins with the following words: Gerardus hujus lucis limen per Venetos parentes Sagredae prosapiae fortitus, Dei gratia praeveniente. . . .., ${ }^{26}$ whilst the Legenda mimor commences with Gaudia, quae Christi participibus dies hodierna contulit, ex beatis patris nostri Christique meritis Gerardi fluxere. Hic enim lucis limen per Venetos parentes sortitus, Dei gratia preveniente. . ${ }^{27}$ This is a classical interpolation on the part of the writer in order to stress Saint Gerard's supposed Sagredo origin.

The Legenda minor is also shortened in some places in Flaminio Corner's lectures. This is clearly stated by Stilting himself, who says that "auctor. . lectiones ex Vita contraxit." The last lecture (no. 6 ) which coincides with $7^{\text {th }}$ chapter of the Legenda minor (according to Madzsar's version in the SRH) is essentially an abbreviated version of the latter. The end of Corner's lecture is completely different from that in the Legenda minor. In the lecture, the ending mentions how Saint Gerard martyrizatus est

${ }^{23}$ Petri de Natalibus, Catalogus sanctorum et gestorum eorum ex diversis voluminus collectus,(Vicenza: Enrico di Ca' Zeno: 1493), (ristampa anastatica, Spoleto: Fondazione C.I.S.A.M. 2012); idem, Catalogus sanctorum et gestorum eorum ex diversis voluminus collectus, (Venetiis 1516): cc. 99v-100; idem, Catalogus sanctorum, Lugduni, 1543, fol. LI (cca 114). On Petrus de Natalibus and his work cf. Emore Paoli. "Il Catalogus sanctorum di Pietro Nadal. Alcune 'istruzioni per l'uso" in Catalogus sanctorum, (Spoleto: Fondazione C.I.S.A.M. 2012) pp. IX-LIII; idem, "Natali, Pietro de"” in: Dizionario Biografico degli Italiani, Volume 77 (2012) http://www.treccani.it/enciclopedia/pietro-de-natali_(Dizionario_Biografico)/ accessed on January 10, 2015

${ }^{24} \mathrm{He}$ lived from 1693-1778. His most famous work is certainly the Ecclesiae Venetae antiquis monumentis nunc etiam primum editis illustratae ac in decades distributae in 8 volumes, with four on Venetian monuments, one volume of Supllementa, one of the Indices and finally three volumes dedicated to the monuments and antiquities of the Ecclesiae Torcellanae. Paolo Preto, "Corner, Flaminio" in: Dizionario biografico degli Italiani Volume 29 (1983), http://www.treccani.it/enciclopedia/flaminio-corner \%28Dizionario-Biografico\%29/ accessed on January 10, 2015. From the second volume, Johannes Stilting took the Lectiones and incorporated them at the end of the hagiographic piece on Saint Gerard of Cenad. (Ex editione Cl. Viri Flaminii Cornelii part. 2 Eccl. Torcel, AA SS septembris VI, 726)

${ }^{25}$ Both appendices are in AA SS septembris VI, 725-727. As far his origin from the Sagredo family is concerned, it is most likely that either some tradition and hagiographic mistake, or simply a forgery created by Petrus Natalibus. Luigi Canetti, “Gerardo di Csanád”, in: Dizionario Biografico degli Italiani, Volume 53 (2000) http://www.treccani.it/enciclopedia/gerardo-di-csanad_\%28Dizionario-Biografico\%29/ accessed on January 10, 2015. In the only completed preserved work of Saint Gerard, the Deliberatio, he also uses the term Pannonia instead of Hungaria, see E. Nemerkényi, Latin Classics, 75.

${ }^{26}$ AA SS septembris VI, 726.

${ }^{27}$ SRH II, 471. 
anno domini millesimo centesimo sexagesimo nono, octavo kalendae Octobris, post beatum Thomam martyrem Cantuariensem episcopum, qui illo tempore fuit. This is a clear mistake, since Saint Thomas Becket, the Archbishop of Canterbury, was martyred more than a century after Saint Gerard. Corner has two errors here, as Saint Thomas Becket died in 1170, not a year before, while it is already known that Gerard was executed during the Vata pagan uprising in $1046{ }^{28}$

However, Corner's work becomes problematic from a historiographical point of view. Unlike in his work on the history of Venice, the Ecclesiae Venetae antiquis monumentis nunc etiam primum editis illustratae ac in decades distributae, or his other work, the Creta Sacra, in the Ecclesiae Torcellanae, from which the Bollandist writer took a passage, Flaminio Corner did not provide any notes. Readers and scholars do not know which documents or sources he used when compiling this work. It is, nevertheless, a remarkable piece of literary work. It would seem that in this phase of his work, Corner becomes more of a hagiographer, a writer that creates his work under strong spiritual influence. It was not important to him to cite archival documents, sources or earlier authors, but to create a work full of Christian devotion. In this work on the churches of Torcello, Flaminio Corner is more a pious essayist than he is a church historian. On the other hand, both of his works on Venetian churches, and especially Creta sacra, are still of considerable value for historians. When compiling both of them, Corner used the archives of the Republic of San Marco, and he even consulted the papal archives for his work on Cretan bishops of both the Greek and Latin rites. ${ }^{29}$

\section{Concluding remarks}

To conclude, within the context of the eighteenth century, the Bollandists' Life of Saint Gerard written by Johannes Stilting in the Acta Sanctorum is, in and of itself, a valuable source about the saint; but even more, it is a worthy source for a reception of the cult of Saint Gerard in the $18^{\text {th }}$ century. Even though Stilting shows a sophisticated level of criticism and an effort to provide a trustworthy and reliable Life of Saint Gerard of Cenad, the first Hungarian martyr, he still made a considerable number of errors. On the other hand, his desire to provide as critical an edition of the Vita as possible deserves to be acknowledged. Johannes Stilting followed Bollandist methodology, i.e. he followed some research methods of historical science and applied them to this critical hagiography. Stilting consulted a vast number of sources, even though some of them were not of particular importance. He also consulted different compilations of the lives of the saints of the Roman Catholic Church, even though they were of uneven quality and reliability for historians and researchers. As was stressed by Jean Bolland, when writing for Acta Sanctorum, one of the key tasks of the hagiographer is to differentiate the reliable sources from those that should not be used in critical hagiographic analysis. Therefore, the efforts of Johannes Stilting in this particular case concerning the Life of Saint Gerard and the appendices he provides are even more worthy of appreciation as he cites many rarely used authors and gives an important contribution to medieval and early modern history, hagiography, and also literature at the same time. ${ }^{30}$

\footnotetext{
${ }^{28}$ AA SS septembris VI, 7 in the Annotata Johannes Stilting already resolved most of the confusions that occur while reading and comparing Legenda minor with Corner's sermons.

29 "L'ultima fase della serenissima-Cultura e civilta. La cultura." In Storia di Venezia (1998) http://www.treccani.it/enciclopedia/l-ultima-fase-della-serenissima-cultura-e-civilta-la-cultura_(Storia-diVenezia)/ accessed on January 11, 2015

${ }^{30}$ Cf. Hippolyte Delehaye, "Les légendes hagiographiques" (Bruxelles: Société des Bollandistes, 1906), 1-140, 168-190, 241-260; Flor Van Omeslege, "Acta Sanctorum i Bolandistička metodologija u izučavanju hagiografije" In: Sergei Hackel (ed.), Vizantijski svetitelj (Beograd: Pravoslavni bogoslovski fakultet, 2008), 212-221 [“Acta Sanctorum and Bollandist methodology in studying hagiography" in: Sergei Hackel (ed.), Byzantine saint]. If one takes a closer look at the methodology suggested by Delehaye and other Bollandists, both before and after him, it is clear that Johannes Stilting fulfilled most of the steps that founders of critical hagiography considered, and still consider, to be the most important ones.
} 
Of course, Stilting's Life of Saint Gerard of Cenad does have numerous deficiencies. He did show a high level of criticism in his studies of hagiography, but there is still lack of critical approach to some sources and especially towards the work of certain authors. It does seem strange that Johannes Stilting decided to publish Legenda minor rather than the more extensive Legenda maior, even though it is obvious that he knew of it and used it extensively through the work of Arnold Wion. Perhaps the the reason for this is that Stilting had a manuscript from the Belgian abbey of Corsendonk and the edition by the Polish medieval historian Jan Dlugosz from 1511, while the manuscripts of the Legenda maior were not available to him. The Bollandist Life of Saint Gerard of Cenad is a valuable document for studying the life of the first bishop of Cenad and Hungarian protomartyr. In spite of being older and with problematic methodology, from the point of view of modern hagiography and historiography, it would be worth further study from various aspects of this Bollandist piece.

\section{References}

Acta Sanctorum septembris, tomus sextus. Antverpiae, 1757.

Canetti, Luigi. "Gerardo di Csanád." In Dizionario Biografico degli Italiani, Volume 53 (2000) http://www.treccani.it/enciclopedia/gerardo-di-csanad \%28Dizionario-Biografico\%29/ (accessed on January $10^{\text {th }} 2015$ )

Delmelle, Joseph. Abbayes et béguinages de Belgique. Bruxelles: Rossel Édition, 1973.

Derks, K. J. "Stilting (Joannes)." In P. C. Molyhusen en P. J. Blok eds. Nieuw Nederlandsch Biografisch Woordenboek, Tweede deel. col. 1376-1377. Leiden: A. w. Sijthoffs Uitgeversmaatschappij, 1912.

Suyskens "(Constantinus)." In P. C. Molyhusen en P. J. Blok eds. Nieuw Nederlandsch Biografisch Woordenboek, Tweede deel. col. 1396-1397. Leiden: A. w. Sijthoffs Uitgeversmaatschappij, 1912.

Dlugossus, Ian. Vita beatissimi Stanislai Cracoviensis Episcopi. Nec non Legendae Sanctorum Poloniae, Hungariae, Bohemiae, Moraviae, Prussiae et Slessiae patronorum, in Lombardica historia non contentae. Cracoviae. 1511.

Érszegi, Géza. "Jegyzetek.” 182-230. In Érszegi Géza ed. Árpád-kori legendák és intelmek [Érszegi Géza, "Notes" In The Legends and Institutions of the Age of Árpád]., ford. Csóka J. Gáspár et al. Budapest: Szépirodalmi, 1987.

Ferrarius Alexandrinus, Philippus Catalogus sanctorum Italiae in Menses duodecim distributes. Mediolani: Bordonius, 1613.

Font, Márta ed. Dinasztia, hatalom, egyház. Régiók formálódása Európá közepén (900-1453) [Dinasty, power, church. The formation of regions in the Central Europe (900-1453)]. Pécs, 2009.

Grégoire OSB, Réginald. "Wion, Arnold, bénédictin († 1613, ou 1610)." col. 1479-1482. Dictionnaire de spiritualité t. 16: U-Z, Ubald d'Alençon-Zypaeus. Paris: Beauchasne, 2004.

Györffy, György. István király és müve. Budapest: Gondolat, 1983. [Saint Stephen and his work]

Hebenstreit-Wilfert, Hildegard. Wunder und Legenden. Studien zu Leben und Werk von Laurentius Surius (1522-1578). Tübingen: Universität Tübingen, 1975.

Kálmán, Juhász. A csanádi püspökség története. Alapitásától a tatárjárásig [The history of the bishopric of Cenad. From founding to the Tartar invasion]. Makó: Csanád vármegye közönsége, 1930.

Klaniczay, Gábor. “Az 1083. évi magyarországi szenttéavatások.” [Hungarian canonizations in 1083] In Müvelödéstörténeti tanulmányok a magyar középkorról [Studies in medieval Hungarian cultural history], ed. Fügedi Erik, 15-33. Budapest: Gondolat, 1986. 
Kristó, Gyula. 'Megjegyzések az ún. "pogánylázadások" kora történetéhez.' [The notes to the history of the so-called age of the pagan revolts]. Acta Universitatis Szegediensis de Attila József Nominatae. Acta Historica 18 (1965): 1-57.

. Szent István birodalma. A középkori Magyarország története [The Realm of Saint Stephen. A history of medieval Hungary]. Budapest: História-MTA TTI, 2001.

Kühár, Flóris. "Szent Gellért Bakonybélben" [Saint Gerard in Bakonybél]. Pannonhalmi Szemle, II (1927): 304-319.

Legendae sanctorum regni Hungariae. Strasbourg: s. a.

http://oszkdk.oszk.hu/storage/00/00/41/72/dd/1/Inc_463_0025.html

http://oszkdk.oszk.hu/storage/00/00/41/72/dd/1/Inc 463 0026.html

http://oszkdk.oszk.hu/storage/00/00/41/72/dd/1/Inc_463_0027.html

(all accessed January 11, 2015)

"L'ultima fase della serenissima-Cultura e civilta. La cultura." In Storia di Venezia (1998) http://www.treccani.it/enciclopedia/l-ultima-fase-della-serenissima-cultura-e-civilta-lacultura_(Storia-di-Venezia)/ (accessed on January $11^{\text {th }} 2015$ )

Marosi, Ernö. "Saints at Home and Abroad. Some Observations on the Creation of Iconographic Types in Hungary in the Fourteenth and Fifteenth Centuries." In Promoting the Saints. Cults and Their Contexts from Late Antiquity until the Early Modern Period. Essys in Honor of Gábor Klaniczy for his 60th Birthday, ed. Ottó Gecser et al., 175-206. Budapest-New York: CEU University Press, 2011.

McCluskey, Karen. "Official Sanctity alla Veneziana: Gerardo, Pietro Orseolo and Giacomo Salomani." Conserverie mémorielles 14 (2013) http://cm.revues.org/1718 (accessed on 10th of January 2015).

Múcska, Vincent. “Az első magyarországi püspökségekről.” [On the first Hungarian bishoprics]. Fons XII (2005): 5-28.

Nemerkényi, Előd. Latin Classics in Medieval Hungary. CEU Medievalia VI. Debrecen-Budapest: University of Debrecen-Central European University, 2004.

Paoli, Emore. "Il Catalogus sanctorum di Pietro Nadal. Alcune 'istruzioni per l'uso." In Catalogus sanctorum. Spoleto: Fondazione C.I.S.A.M. 2012, IX-LIII.

"Natali, Pietro de"”. In Dizionario Biografico degli Italiani, Volume 77 (2012) http://www.treccani.it/enciclopedia/pietro-de-natali (Dizionario Biografico) (accessed on January 10, 2015)

Pešina z Čechorodu, Tomáš Jan. Phosphorus septicornis. Pragae, 1673.

Petri de Natalibus. Catalogus sanctorum et gestorum eorum ex diversis voluminus collectus. Vicenza:

Enrico di Ca' Zeno: 1493. (ristampa anastatica, Spoleto: Fondazione C.I.S.A.M. 2012.

Petri de Natalibus. Catalogus sanctorum et gestorum eorum ex diversis voluminus collectus. Venetiis, 1516.

Petri de Natalibus. Catalogus sanctorum. Lugduni 1543.

Podlaha, Antonín-Šittler, Eduard. Chrámový poklad u sv. Vita v Praze : Jeho dějiny a popis. Praha: Dědictví sv. Prokopa, 1903. [The Church treasury of Saint Vitus in Prague. Its' history and description].

Preto, Paolo. "Corner, Flaminio." In Dizionario biografico degli Italiani Volume 29 (1983), http://www.treccani.it/enciclopedia/flaminio-corner_\%28Dizionario-Biografico\%29/ (accessed on January 10, 2015).

Szentpétery, Emericus ed., Scriptores rerum Hungaricarum II. Budapestini: Nap, 1999. 
Szovák, Kornel and László Veszprémy. "Krónikák, legendák, intelmek-utószava.” [Chronicles, legends, institutions-epilogue]. In Scriptores rerum Hungaricarum II, ed. Emericus Szentpétery, 720-799. Budapest: Nap, 1999.

Tóth, Péter. "Szent Demeter magyarországi legendája" [The Hungarian legend of Saint Demetrius]. In Szent Demeter. Magyaroország elfeledett védöszentje [Saint Demetrius. The Forgotten protector saint of Hungary], ed. Tóth Péter, 40-93. Budapest: Balassi, 2007.

Van Hulthem, Ch. dél.. Bibliotheca Hulthemiana. Manuscrits. Gand. 1837.

Van Omeslege, Flor. "Acta Sanctorum i Bolandistička metodologija u izučavanju hagiografije." 210221 In Sergei Hackel ed. Vizantijski svetitelj ["Acta Sanctorum and Bollandist methodology in studying hagiography” in Byzantine saint]. Beograd: Pravoslavni bogoslovski fakultet, 2008.

Zsoldos, Attila. Magyarországi világi archontológiája 1000-1301 [The laic arhcontology of Hungary 1000-1301]. Budapest: MTA TTI, 2011. 